\title{
Mangrove Degradation: Issue and awareness
}

\section{Mazni Adibah Abd Rahman, M. Zainora Asmawi}

\author{
Department of Urban and Regional Planning, \\ International Islamic University Malaysia, Malaysia \\ diebarahman89@gmail.com
}

\begin{abstract}
Mangroves in Malaysia reside coastlines and the largest areas of mangrove are in the Northern Sabah. They sheltered at the shores of the west coast. Over four decades, mangroves are recorded to be declining due to aquaculture practices implemented in Peninsular Malaysia. Public participation and their awareness are considered as critical components in conserving the mangrove areas. Thus, the research was conducted to discover residents' awareness towards this devastating issue. A questionnaire survey was employed to respondents in Kuala Selangor. In this regards, this research is to study the residents' awareness on the importance of mangrove areas.
\end{abstract}

Keywords: Mangrove Forest; Degradation; Awareness; Kuala Selangor

eISSN 2398-4279 @ 2018. The Authors. Published for AMER ABRA cE-Bs by e-International Publishing House, Ltd., UK. This is an open access article under the CC BY-NC-ND license (http://creativecommons.org/licenses/bync-nd/4.0/). Peer-review under responsibility of AMER (Association of Malaysian Environment-Behaviour Researchers), ABRA (Association of Behavioural Researchers on Asians) and $c E-B s$ (Centre for EnvironmentBehaviour Studies), Faculty of Architecture, Planning \& Surveying, Universiti Teknologi MARA, Malaysia.

DOI: https://doi.org/10.21834/ajqol.v3i10.104 


\subsection{Introduction}

This study is to emphasize the awareness level of the residents in the management of mangrove forest in Kuala Selangor. Irrespective of the fact that on that point are many profound researchers conducted several studies on the management of mangrove forest, there are nonetheless a bunch of doubts and inquiries on that topic. Such as; how far do the local resident's actions and awareness make a difference in mangrove rehabilitation? Several researchers have come to an agreement on the idea of mangrove depletion all around the world; in Thailand, Indonesia, Malaysia and many other countries. The reasons for these happenings resulted from human activities; for example, conversion to agriculture and salt production, coastal industrialization, conversion to aquaculture and others. For instance, in Thailand, mangrove forests are lost to shrimp ponds and coastal developments (Macintosh, Ashton \& Havanon, 2002). Moreover, difficulties in implementations, budget shortage and lack of experts in the matter make it harder for the authority to manage mangrove forests in Kuala Selangor.

In essence, this study provides a better understanding of the residents on their awareness and acceptance regarding this issue. Furthermore, the economy of Kuala Selangor plays an important part in the development of Selangor per se. With that, the resident's awareness is crucial and significant in planning a better head for Kuala Selangor at par with the increasing number of residents and the environment.

Thus, the residents' awareness and involvement in this pertaining matter are important and crucial in helping the authority or planning department to plan ahead for the development of Kuala Selangor. Knowledge of the residents determines the effectiveness of rehabilitation program done by either the Government body or the Non-Government body. A good and successful environment management depends on the awareness that depicted entirely in accommodating the issues and problem while rehabilitation programs are well implemented and enforced. Therefore, it is the argument of this research that there is not enough awareness in some of the residents, and the lack of this awareness might just be the reason for poor participation in mangrove rehabilitation programs.

\subsection{Literature Review}

Studies on mangroves and its' ecosystem are massive in number and worldwide in the division. They provide an overview of the mangrove ecosystem and its' biodiversity, management aspects, status and trends, values and depleting causes (Field, 1998; Kamaruzaman \& Dahlan, 2008; Food \& Agriculture Organization [FAO], 2007; Macintosh, Ashton, and Havanon, 2002; and Kathiresan, n.d.). Mangrove lands are always described as an 'eyesore' (Kamaruzaman \& Dahlan, 2008) and 'wasteland' (Choudhury, n.d.) that carries meaningless existence of it. However, awareness of mangrove loss has opened the eyes of many profound researchers and other stakeholders worldwide.

As a matter of fact, knowledge on this issue has been increasing recently and has led more efforts and actions in protecting the ecosystem. Rehabilitation and restoration programs are initiated and increasingly organized by either local authorities or international commitment organizations. Rehabilitation is defined as an act of getting the ecosystem back into its' 
original condition through many means (Field, 1996 in Macintosh et al., 2002). In restoring the system, there are numbers of action which helps the ecosystem to heal. Among these actions, tree planting is the most widely used methods. However, this effort might be jeopardized by the action of just planting the trees without proper site assessment, evaluation and tree-handling technique. Other methods that one could use in restoring mangrove forest or by habitat creation through converting the tarnished area to a suitable substitute (Stevenson et al., 1999 in Macintosh et al., 2002).

\section{Threats and changes in mangrove areas.}

Arriving in the millennium year in 2000 , a powerful anthropogenic change is seen where the number of people is increasing drastically from 1.5 billion to 6.0 billion (Valiela, et. al., 2009). Thus, demand for energy, food, water and other resources have increased unreasonably in certain regions of the world. Human living in an aggregated manner requires greater demands on resources while consuming a more significant amount of energy due to the need for transportation, heating, cooling and water supply and so on. In some parts of the world, a large area of the natural environment is sacrificed for the building of the built environment.

Numbers of researchers came to an agreement and supported the issue of mangroves continue to disappear all over the world. In general, mangrove forests are under heavy human pressure. Beside human influences, they are also suffering from environmental stress factors. Some estimation was done by the researcher saying that with the current annual loss rate, some region might ultimately lose the beauty of this ecosystem. Habitat destruction through human encroachment has been the primary cause of mangrove loss. The damage is known by man either knowingly or unknowingly of the mangrove values. Resulted from this loss, fishery sources, livelihood, biodiversity are reported to be continuously declining. The cause of mangrove destruction varies for each country. Some countries are impacted by aquaculture activities, high demand for land for housing and industries, agriculture conversion, commercial logging, charcoal and fuelwood industries and land reclamation for urban development.

\section{Public awareness of the environmental issue.}

Public awareness of both the biological and economical importance of natural resources and the need for proper management is crucial to improve the environmental quality as a whole. According to Scoullos and Brouma (2002), the best way to obtain a good level of public awareness and participation is by respecting institutionalized and voluntary rules agreed by understanding dialogue, participation and partnership. Also, Sayers (2006) suggest that to raise awareness is by informing and educating people about a topic or issue with the intention of influencing their positive attitudes, behaviors and beliefs towards the achievement of a definite purpose of goal in the subject matter. In the local context, it is undeniable a fact that public awareness is very important in the related environmental issues (Wong, 2006). Wong (2006) says that the increasing level of awareness of the local community is the first step in empowering the local participation in planning and managing their natural resources. A study in Kuala Selangor mentions about the importance of awareness among the local residents to get involved in conserving the natural resources (Mazni Adibah and Zainora, 2015). 


\section{Mangroves in Malaysia.}

Until the year 2008, the total forested area in Malaysia is recorded to 19.52 million hectares or about 59.5 percent of the total area (Forest Department Peninsular Malaysia; Forest Department Sabah \& Forest Department Sarawak in Forest Research Institute Malaysia, 2012). Out of that value, about 0.58 million hectares are mangrove with the dominance in Sabah.

Mangroves in Peninsula Malaysia are found wild in the sheltered coastlines of Kedah, Perak, Selangor, and Johor; that was bordered by the Straits of Malacca. Perak holds the record for the highest area covered with mangrove forest. In the east coast of Peninsula Malaysia, mangroves are documented sheltering the estuaries of the Kemaman River in Terengganu and Bear River in Pahang (Forest Research Institute Malaysia, 2012).

Peninsula Malaysia is bordered by the South China Sea in the east, Straits of Johor in the South, Straits of Melaka in the West and Malaysia-Thailand land border in the North. These coastlines run about 1,972 kilometers all the way. 72 per cent of the Peninsula west shores are made up of mud coasts while sandy beaches are on others (Forest Research Institute Malaysia, 2012). Most mangroves in Malaysia are documented to habit in the west coast as it is calmer from waves and winds (Refer table 2). Differs to the east coast where on pockets of mud are found in the mangrove ecosystem.

\subsection{Methodology}

\section{Case Study: Matang Mangrove Forest Research}

Malaysia is proud to announce and acknowledge the treasure of Matang Mangrove Forest Reserve (MMFR) as the Best Managed Forest District in Malaysia in 1996/1997 (Malaysian Timber Council, 2009). It is situated on the northwestern coast of Peninsula Malaysia and under the jurisdiction of Larut Matang and Kerian, Perak. More than 70 percent of the forest area is classified under productive forest while less than 30 percents are the non-productive or protected area (Malaysian Timber Council, 2009).

Management of MMFR is divided and guided by the Perak State Forest Department based on the ten years Working Plan and Detailed Control Maps (Malaysian Timber Council, 2009). Until 2014, management of MMFR has evolved in many levels. Hence, this has not only allowed in supplying raw material for charcoal production but also all year round fishing activity. The ultimate aim of MMFR management is to go sustainable.

This study has two components where first a collection of several literature reviews with as many keywords related to the topic such as community involvement, managed mangrove, mangrove depletion, public awareness and wetland management was conducted. The research study was carried out to form the theoretical foundation of the study and to aid the analysis of the outcome. The second component of the study is the research questions, objective, and questionnaire formulated by the researcher.

The aim of this study is to acknowledge, the awareness level and education spread of 
the residents in Kuala Selangor concerning the issue of mangrove depletion. Based on the literature review, field works and questionnaire survey (sampling size is 103) were deployed to provide a better understanding of the awareness from the local community on the participation at the local level.

\subsection{Findings and Discussions}

In the first cross-tabulation is a relation between the respondent's gender, a multi-option question on responsible taking care of the mangrove forest and have they ever visited mangrove forests in Malaysia. The result shows that a total of 46 respondents is choosing "public" and have been visiting mangrove forest at a minimum once a year. It shows that they who have visited mangrove forest agreed to the matter of fact that environment needs the care and awareness of the public also, instead of waiting the concern given by the government. No doubt that the government has massive things to deal with it. However, far from assuming that mangrove is out of Government's jurisdiction. It is a good management where the public could help, hand-in-hand alongside with the Government as well the NonGovernment bodies in protecting our mangrove forest. On two separate occasions, those respondents who have not yet visited mangrove forest, chooses Government's responsibility in protecting the environment with 25 respondents; nine males and 16 females (Refer table 1). Governments are precisely responsible for appointing laws and enforcement of certain legislation; including penalizing those who offended the rules and regulations.

Table 1: A cross-tabulation between gender, responsibilities and visiting mangrove forest.

\begin{tabular}{|c|c|c|c|c|c|c|}
\hline \multirow{2}{*}{\multicolumn{3}{|c|}{ Have/not visited mangrove forest. }} & \multicolumn{3}{|c|}{ Responsibilities } & \multirow[b]{2}{*}{ Total } \\
\hline & & & Public & Government & $\begin{array}{l}\text { Non- } \\
\text { Government }\end{array}$ & \\
\hline \multirow[t]{3}{*}{ YES } & \multirow[t]{2}{*}{ GENDER } & MALE & 17 & 28 & 19 & 38 \\
\hline & & FEMALE & 29 & 17 & 16 & 34 \\
\hline & \multicolumn{2}{|l|}{ Total } & 46 & 45 & 35 & 72 \\
\hline \multirow[t]{3}{*}{ NO } & \multirow[t]{2}{*}{ GENDER } & MALE & 5 & 9 & 5 & 9 \\
\hline & & FEMALE & 15 & 16 & 6 & 22 \\
\hline & \multicolumn{2}{|l|}{ Total } & 20 & 25 & 11 & 31 \\
\hline
\end{tabular}

Secondly, from the cross tabulation between education level, visited mangrove forest or not and the awareness of the matter. The highest number of awareness among the respondents is among those who visited mangrove forests at the minimum of once a year. Out of that figure, 27 respondents are recorded to have "moderate awareness" on the mangrove degradation issue, followed up by the 19 respondents with "total awareness" (Refer table 2). The highest frequency of "not aware" of this matter is among those who have not visited mangrove forests; with 13 out of 31 respondents, and can be classified as having zero knowledge of mangrove forest. About the literature review, the result demonstrates that 
education is essential to elevate the level of local residents. Respondents with secondary education level, however, dominating the number of interviewees which has been visiting mangrove forest. They can be classified as having a minimum knowledge of mangrove forest.

Table 2: A cross-tabulation between awareness, education level and visiting mangrove forest.

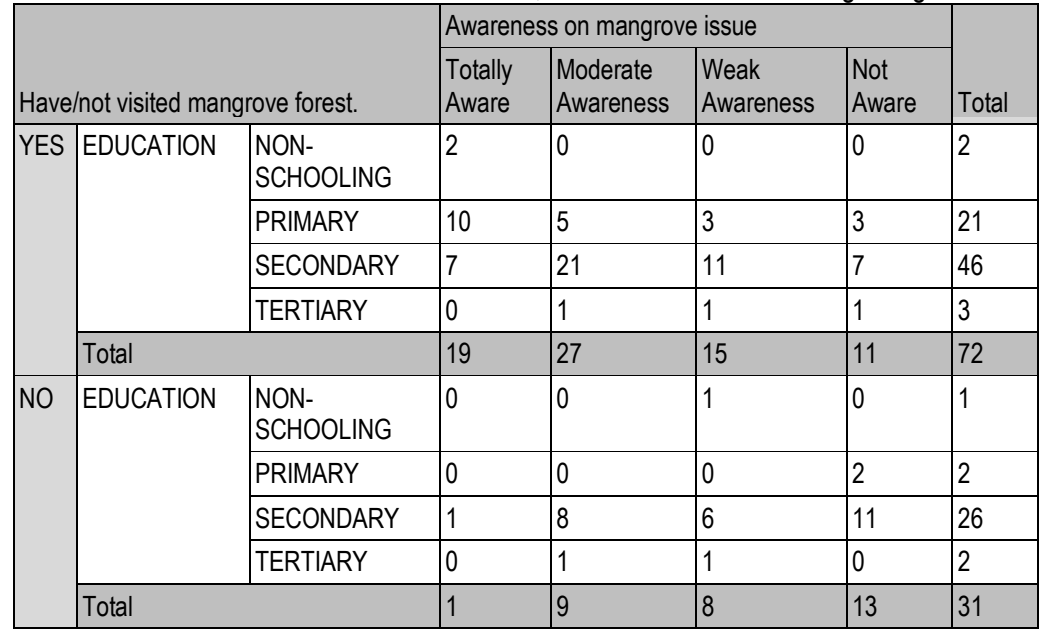

Source: Thesis Study, 2015

On the other hand, a cross-tabulation data is made between reasons of mangrove depletion, visiting the mangrove forest and gender. Table 3 shows that a total of 42 respondents choose illegal logging from 69 respondents who have visited mangrove forest. They have eventually witnessed and experienced the situation and considered as illegal logging as the main factor of mangrove degrading. Some 34 respondents also agreed that urbanization also contributed to the depletion (Refer table 3 ). Overall, agriculture is seen as an unimportant factor. However, in some countries, they cut down mangrove forests in giving ways and land for agricultural activities.

As a matter of fact, public awareness of mangrove forest is still on the brink. People are not entirely aware of the fact that we are losing more mangrove forest than what we plant regarding rehabilitating the source. Respondents have suggested and agreed to the statement that the public need more exposure and education on mangrove forest. Thus, this indicates that efforts from various players such as the Government and Non-Government, alongside the locals are essential in ensuring the protection of our valuable mangrove forest for the future generations. Consequently, the public felt that enforced legislation by the legal body is crucial to support mangrove management practice. 
Table 3: A cross-tabulation between reasons of mangrove degradation, visiting mangrove forest and gender.

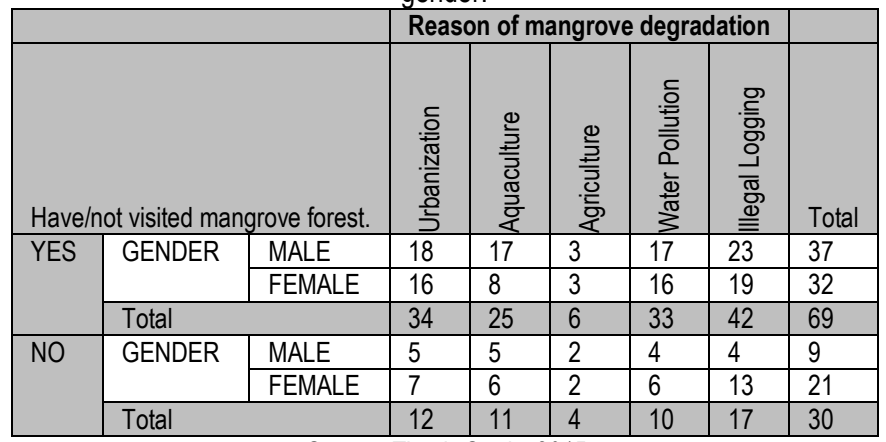

Source: Thesis Study, 2015

\subsection{Conclusion}

Throughout the study, it has been argued that the lack of local community awareness is considered as the main problem in weakening the local community participation in mangrove management. The outcome of this study has demonstrated clearly that the lack of awareness efforts leads to less information being received by the local witch eventually cause poor participation in mangrove management in Kuala Selangor. Thus, public understanding and awareness in regards to the mangrove biological and economy values are vital to ensuring the proper administration of this resource. The importance of environmental education is considered as the potential tool to elevate the residents' knowledge, understanding and awareness on the mangrove ecosystem. It is hoped that this research has contributed to the body of knowledge as well as this is also related to the achievement of sustainable development, concerning the future generations. Stewardship of the mangrove ecosystem and good management depends wholly on this generation and next generation to come. The younger generation must, therefore, take the lead and show some interest in caring the environment for a safer, healthier and brighter future.

\section{References}

Choudhury, J. K. (n.d.). Sustainable Management of Coastal Mangrove Forest Developmnet and Social Needs. Mangroves and Other Coastal Forests, 267-286.

D.J.Macintosh, E. S. (2002). Mangrove Rehabilitation and Interval Biodiversity: A study in the Ranong Mangrove Ecosystem. Estuarine, Coastal and Shelf Science, 331-345.

Field, C. (1998). Rehabilitation of Mangrove Ecosystem: An Overview. Marine Pollution Bulletin, 37 (8-12), 383-392.

Forest Research Institute Malaysia. (2012). Status of Mangroves in Peninsular Malaysia. (O. Hamdan, Ed.) Malaysia: Gemilang Press Sdn Bhd. 
Irini, Ibrahim \& Norazlina, Abdul Aziz. (2012a). The roles of international NGOs in the conservation of Bio-Diversity of Wetlands, Procedia: Social \& Behavioral Science,40, 242-247.

Irini, Ibrahim; Noraini, Abdullah \& Micheal, A. Y. @ Suleiman Abdullah Ibn Yahya. (2012c)., Education for wetlands: Public perception in Malaysia, Procedia Social \& Behavioral Sciences, Elsevier, 42, 159-165.

Irini, Ibrahim; Norazlina, Abdul Aziz, \& Norha, Abu Hanifah. (2012b). The Laws of Wetness: The Legislative Framework in Malaysia Regarding Wetlands Conservation, Procedia: Social \& Behavioral Sciences. Elsevier, 50, 574-581.

Kamaruzaman Jusoff., \& Dahlan Taha. (2008). Managing Sustainable Mangrove Forests in Peninsular Malaysia. Journal of Sustainable Development, 1 (1), 88-96.

Kathiresan, K. (n.d.). Degradations and Destruction of Mangroves. Threats to Mangroves.

Macintosh, D., Ashton, E., \& Havanon, S. (2002). Mangrove Rehabilitation and Intertidal Biodiversity: A Study in the Ranong Mangrove Ecosystem, Thailand. Estuaries, Coastal and Shelf Science (55), 331-345.

Malaysian Timber Council. (2009). Matang Mangroves: A Century of Sustainable Management. Timber Malaysia, $15(3), 6-11$.

Mazni Adibah Abd Rahman \& M.Zainora Asmawi. (2014). Mangrove forest: degradation and rehabilitation. UMRAN 2014 Seminar: Fostering Ecosphere in the Built Environment, 29 April 2014, Kulliyyah of Architecture and Environmental Design, IIUM.

Scoullos, M. J. \& Brouma, A. D. (2002). Water Governance in the Mediterranean Region and Public Involvement.

Valiela, I., Kinney, E., Culbertson, J., Peacock, E., \& Smith, S. (2009). Chapter 4: Global Losses of Mangroves and Salt Marshes. In C. M. Duarte, Global Loss of Coastal Habitats, Rates, Causes and Consequences (pp. 109-120).

Wong, E. (2006). Public Participation in Environmental Planning and the Preparation Process of Local Plans. Paper presented at the Fourth Sabah-Sarawak Environmental Convention. 